\title{
The Development of Mathematical Model of Gas-Turbine Unit Combustion for Chamber Functioning
}

\section{Introduction}

The problem of lowering the toxicity of combustion products of gas dispensing units (GDU) being operated at the compressor stations of the main gas pipelines is the constituent of the scientific and technical progress of the natural gas industry [1]. The key standards, that the low emissive combustion chambers are up to, have already been settled, based on the main ways of the working process arrangement and the tendencies of operations efficiency improvement of the fuel scorching devices [2-7]. For their manufacturing application it is indispensable to increase the design efficiency and improvement of the low emissive combustion chambers.

\section{Analysis of Present-Day Foreign and Domestic Studies and Published Works}

The main courses of the lowering the toxicity of combustion products in the burning systems of various purposes are: the application of increased air surpluses (V.A. Khrystych, G.N. Liubchyk, N.K. Risk, D. Wels); the application of phasic combustion (I.Ya. Sigal, F.G. Tumanovskii, A. Lefer); the homogenization of the combustion area (G. Leonard, S.M. Korea); the application of micro torch combustion (S.D. Serdiuk, N.P. Danylenko, G.B. Varlamov, A.M. Markushin, A.M. Postnenkov, V.P. Savchenko); the application of catalytic combustion technologies (G.N. Liubchyk, G.S. Marchenko, B.I. Shelkovskii, C. Wilkes, S.V. Santanam).

The test results of the Solar company device (in the combustion chamber GDU GTC-10I) [8] demonstrated that when increasing the air surplus over the above-mentioned level the $\mathrm{CO}$ emission increases roughly. Considering the air surplus ratio $\alpha \rightarrow 2.0$ the $\mathrm{CO}$ in the combustion products leads to $\mathrm{O}_{2}=15 \%$, and results

\footnotetext{
* Ivano-Frankivsk National Technical University of Oil and Gas, Ivano-Frankivsk, Ukraine
} 
in $100 \mathrm{mg} / \mathrm{m}^{3}$, that can cause the increased chemical deficiency of fuel combustion. Consequently, when decreasing the air surplus below the above-mentioned level not only the $\mathrm{NO}_{x}$ and $\mathrm{CO}$ are essentially increased but also there is a high-frequency combustion, breakdown and a sudden flame [8]. The companies that use the given technology (such as: Solar, Rolls-Royce, Siemens etc.) eliminate such a failure using the complex systems of regulating the mix proportion in the combustion area, and variable geometry of the combustion chambers and flow-type part of a compressor. The simulation of the working processes in the combustion chambers is considered to be one of the perspective methods that enable the cost of the research to be reduced. In particular, the mathematical model of three-dimensional chemically reacted flows, engineered by G.B. Mostipanenko, enables the prediction of the output temperature and ecological features of the combustion chambers that use the gaseous fuel.

\section{Emphasizing Unresolved Issues of the Common Problem}

At no section of gas route of the gas-turbine unit is measured either the air consumption or the actuating medium. Moreover, the records done by the existing methods are impossible, as it leads to the hydraulic losses that reduce the capacity and the economic efficiency of the cycle. The single consumption that can be measured practically is the consumption of fuel gas. Evidentially, its component analysis can be considered to be known.

The objective of the research is to develop the mathematical model diagnostics of combustion chamber considering the basic parameters of gas-turbine unit operation under different technological modes including the intake air temperature of the axial-flow compressor, the intake temperature of the actuating medium of the directing set of the high pressure turbine as well as the temperature of the environment.

\section{Reporting the Principal Subject Matter}

The combustion chamber of gas-turbine unit is specified for the actuating medium preparation that when expanding at the turbine trowel will perform the useful work. For this purpose in the combustion chamber the gas fuel takes place in the primary air medium with the creation of pure combustion products and the process of mixing with the reiterative air for obtaining the admissible temperature of the actuating medium. Hence the composition of the actuating medium can be given like the mixture of the pure combustion products with the reiterative air. For description of the actuating medium is given the concept of the air surplus coefficient $\alpha$, which is the ratio of total air consumption (primary $L$ and reiterative $L_{0}$ ) to the primary air consumption, theoretically necessary for combustion of $1 \mathrm{~kg}$ of fuel gas [1]: 


$$
\alpha=\frac{L+L_{0}}{L_{0}}
$$

The required quantity of air for combustion of $1 \mathrm{~kg}$ of fuel gas of the known component composition with the density $\rho^{\prime}$ in theory can be computed in the following way:

$$
\begin{aligned}
L_{0}= & \frac{1.293}{21 \rho}\left[0.5(\mathrm{CO})+0.5\left(\mathrm{H}_{2}\right)+2\left(\mathrm{CH}_{4}\right)+\right. \\
& +\sum(m+n / 4)\left(\mathrm{C}_{m} \mathrm{H}_{n}\right)+1.5\left(\mathrm{H}_{2} \mathrm{~S}\right)-\left(\mathrm{O}_{2}\right)
\end{aligned}
$$

Here the symbols in the brackets mean the volumetric bits of every component in the mixture of gases. The air surplus in the combustion chamber in comparison with its theoretically indispensable quantity leads to the cooling of the actuating liquid. The air surplus coefficient is related to the maximum temperature of the ratio cycle:

$$
\alpha=\frac{Q_{H}^{P} \eta_{k c}+C_{g} t_{g}+C_{P}^{\prime \prime} t_{3}}{L_{0}\left(C_{P}^{\prime \prime} t_{3}-C_{P}^{\prime \prime} t_{2}\right)}
$$

where $C_{g^{\prime}} t_{g}$ - the heat capacity and temperature of the fuel gas.

Without determining the heat value of the fuel $Q_{H}^{p}$ and its heat capacity $C_{p}$ it is pointed out that the air surplus coefficient can be found from the equation (3) on the basis of the fuel gas temperature dimension $t_{g}$ the air after the axial-flow compressor $t_{2}$ and the actuating liquid before the gas turbine $t_{3}$. Then the mass consumption of the actuating liquid and air can be shown through the mass consumption of the fuel gas.

$$
\begin{aligned}
& M^{\prime \prime}=\alpha\left(L_{0}+1\right) M_{g} \\
& M^{\prime}=\alpha\left(L_{0}-1\right) M_{g}
\end{aligned}
$$

The volumetric air consumption is set to the input conditions of the first grade of the axial-flow compressor:

$$
Q_{1}=\frac{L_{0}(\alpha-1) M_{g}}{P_{1}} 287 T_{1}
$$


Thus, using the equations (3) and (6) it can be determined the productivity of the axial-flow compressor that will enable a definition of the diagnostic features for every mode of the gas turbine unit. However, for the application of the equation (3) it is indispensable to determine the mean specific volume of the air heat capacity $C_{m}^{\prime}$ in the temperature span $\left(t_{1}, t_{2}\right)$ and the actuating medium $C_{p^{\prime} m^{\prime}}^{\prime \prime}$ in the temperature span $\left(t_{4}, t_{3}\right)$. If there is no difficulty in determining the air heat capacity that is a mean in the known temperature span there is some difficulty in determining the mean mass heat capacity of the actuating medium $C_{p^{\prime} m^{\prime}}^{\prime \prime}$ as the composition of the actuating medium is unknown. Consequently for the computation of the air surplus coefficient is worth applying the method of successive approximation.

The computation algorithm is the following:

1. In the first approximation are specified the values of actuating medium heat capacity $C_{p^{\prime} m^{\prime}}^{\prime \prime}$ that is equal to the air heat capacity with the same data:

$$
C_{p m}^{\prime \prime}=C_{p m}^{\prime}
$$

2. When using equation (3) it is computed the first approximation of the air surplus coefficient.

3. It is computed the mass consumption of the actuating medium on the assumption that of $1 \mathrm{~kg}$ of fuel gas consumption:

$$
M^{\prime \prime}=M_{\mathrm{CO}_{2}}+M_{\mathrm{H}_{2} \mathrm{O}}+M_{\mathrm{N}_{2}}+M_{\mathrm{O}_{2}}
$$

where:

$$
\begin{gathered}
M_{\mathrm{CO}_{2}}=\frac{0.44}{22.4}\left[\left(\mathrm{CO}_{2}\right)+(\mathrm{CO})+\sum m\left(C_{m} H_{n}\right)\right] \\
M_{\mathrm{H}_{2} \mathrm{O}}=\frac{0.18}{22.4}\left[\left(\mathrm{H}_{2}\right)+2\left(\mathrm{CH}_{4}\right)+\sum \frac{n}{2}\left(C_{m} H_{n}\right)\right] \\
M_{\mathrm{N}_{2}}=0.769 L_{0} \alpha^{(1)} \\
M_{\mathrm{O}_{2}}=0.231 L_{0}\left(\alpha^{(1)}-1\right)
\end{gathered}
$$

4. It is computed the mass bits of every given component in the actuating medium:

$$
\begin{array}{ll}
m_{\mathrm{CO}_{2}}=M_{\mathrm{CO}_{2}} / M^{\prime \prime} & m_{\mathrm{H}_{2} \mathrm{O}}=M_{\mathrm{H}_{2} \mathrm{O}} / M^{\prime \prime} \\
m_{\mathrm{O}_{2}}=M_{\mathrm{O}_{2}} / M^{\prime \prime} & m_{\mathrm{N}_{2}}=M_{\mathrm{N}_{2}} / M^{\prime \prime}
\end{array}
$$

5. It is computed the heat capacity of the actuating liquid:

$$
C_{p m}^{\prime \prime}=m_{\mathrm{CO}_{2}} C_{p m}^{\mathrm{CO}_{2}}+m_{\mathrm{H}_{2} \mathrm{O}} C_{p m}^{\mathrm{H}_{2} \mathrm{O}}+m_{\mathrm{O}_{2}} C_{p m}^{\mathrm{O}_{2}}+m_{\mathrm{N}_{2}} C_{p m}^{\mathrm{N}_{2}}
$$


6. When using equation (3) it is defined more accurately the air surplus coefficient and computed the calculations till achieving the given accuracy:

$$
\left|\alpha^{i-1}-\alpha^{i}\right|<\varepsilon_{0}
$$

The complex processes happening in the combustion chamber demand the hypothesis admission while formalizing. So that, for the narrow range of the air surplus coefficient change in the burning part of the combustion chamber, it can be admitted that the combustion temperature doesn't depend on the air surplus and is constant.

When admitting the pressure and temperature after the axial-flow compressor as well as air and fuel gas consumption to be known, then for the motion in the combustion chamber it can be given the following system of differential equations:

$$
\left\{\begin{array}{l}
\frac{d P}{d t}+\frac{c^{2}}{F}\left(\frac{d M^{\prime}}{d x}+M L_{0}(\alpha+1) \delta\left(x-x_{0}\right)\right)=0 \\
\frac{d P}{d x}+\left(\xi_{k} / 2 p F^{2}\right) M^{2}+\frac{1}{F} \frac{d M}{d t}=0 \\
\frac{d M}{d t}+\frac{M^{\prime}}{\rho^{\prime} F} \frac{d T}{d x}+\frac{M L_{0}(\alpha+1) C_{p}^{\prime}}{p^{\prime \prime} C_{p}^{\prime \prime} F} T_{2} \delta\left(x-x_{0}\right)-\alpha \frac{d^{2} T}{d x^{2}}-\frac{\pi D\left(T_{0}-T\right)}{p^{\prime \prime} C_{p}^{\prime \prime} F}=0
\end{array}\right.
$$

The link between the basic parameters of the actuating medium (pressure $P$, temperature $T$ and mass consumption $M$ ) for different periods of time and various parts of the combustion chamber that are characterized with the linear coordinate $x$ can be given with the above-mentioned equations. At the point of combustion and mixing $\left(x=x_{0}\right)$ it can be observed the step consumption increase, caused by the reiterative air supply with the consumption $M_{1}$. Thus, the actuating medium consumption as a function of the linear coordinate can be given in the following equation:

$$
M=M_{r}\left(L_{0}+1\right)+M^{\prime} L_{0}(\alpha-1) \sigma\left(x-x_{0}\right)
$$

where:

$$
\begin{aligned}
& L_{0} \text { - theoretically indispensable air for combustion of } 1 \mathrm{~kg} \text { of fuel, } \\
& \alpha \text { - air surplus coefficient, } \\
& \sigma\left(x-x_{0}\right) \text { - Heaviside's unit function: }
\end{aligned}
$$

$$
\sigma\left(x-x_{0}\right)=\left\{\begin{array}{lll}
1, & \text { if } & x>x_{0} \\
0, & \text { if } & x<x_{0}
\end{array}\right.
$$


For simulating the step change of temperature consumption in the point of supply of the reiterative air $\left(x=x_{0}\right)$ it is given the Dirac's function of source in the equations $\delta\left(x=x_{0}\right)$. It is worth considering that for some combustion chambers the diameter $D$ and the sectional area $F$ can be changed on the linear coordinate $x$. The air density $\rho^{\prime}$, actuating medium $\rho^{\prime \prime}$, and pure combustion products $\rho$ when there are the specified conditions in the combustion chamber can be shown through pressure and temperature:

$$
\rho^{\prime}=\frac{P}{R^{\prime} T}, \quad \rho^{\prime \prime}=\frac{P}{R^{\prime \prime} T}, \quad \rho=\frac{P}{R T}
$$

Thus, the system (13) is the closed system of the differential equations that combine the parameters of the combustion chamber functioning with its typical dimensions and physical properties of the actuating medium. The system includes also the coefficient of the hydraulic resistance of the combustion chamber $\xi_{k}$ and the coefficient of the heat exchange with the environment. The gas-turbine units operation proved that exactly these coefficients demonstrate the real condition of the combustion chamber. So, the coefficient of the hydraulic resistance of the combustion chamber and the absolute coefficient of the heat exchange with the environment can be used as the diagnostic features. The simplification of the mathematical model given in the equation (13) for the standard mode has been performed due to the division of the gas dynamic and thermodynamic processes. For the permanent gas dynamic process in the combustion chamber the equation of motion can be presented in the following way:

$$
\frac{d P}{d x}=-\frac{\xi_{K} M^{\prime \prime 2}}{2 D \rho F^{2}}
$$

The actuating medium consumption can be determined through the measured consumption of the fuel gas $M_{g}$ and the coefficient of the air surplus in the combustion chamber computed by the approach given above:

$$
M^{\prime \prime}=\alpha\left(L_{0}+1\right) M_{g}
$$

Through the computed composition of the actuating medium it can be determined its gas constant from the equation:

$$
\frac{1}{R^{\prime \prime}}=\sum_{i=1}^{4} \frac{m_{i}}{R_{i}}
$$

where $m_{i^{\prime}} R_{i}$ - mass fractions of the $i$ component in the actuating medium and its gas constant. The mean pressure and temperature in the mixing zone are computed as the arithmetic mean: 


$$
\begin{aligned}
& P_{c}=\frac{1}{2}\left(P_{2}+P_{3}\right) \\
& T_{c}=\frac{1}{2}\left(T_{2 L}+T_{3}\right)
\end{aligned}
$$

where:

$P_{2^{\prime}} P_{3}$ - the input and output pressures of the combustion chamber, that are determined via measurements,

$T_{2 L}$ - the intake air temperature of the mixing zone of the combustion chamber, the approach of determining it will be given later,

$T_{3}$ - the measured temperature at the output of the combustion chamber.

Then, the density of the actuating medium under the average conditions in the combustion chamber can be determined from the equation of the state:

$$
\rho=\frac{P_{c}}{R^{\prime \prime} T_{c}}
$$

The answer from the equation (17) can be given in the following way:

$$
\frac{P_{2}-P_{3}}{L}=\frac{\xi_{k} M^{\prime \prime 2}}{2 \rho F^{2}},
$$

where $L, F-$ are the length and the area of the section of the combustion chamber correspondingly.

From equation (22) it can be computed the coefficient of the resistance of the combustion chamber as the following:

$$
\xi_{k}=\frac{2 \rho F^{2}\left(P_{2}-P_{3}\right)}{L M^{\prime \prime 2}}
$$

The permanent heat exchange of the actuating medium that moves in the flue tube after the mixing zone with the flow of the reiterative air in the conditions of counterflow can be given as:

$$
K_{1} \pi D\left(T_{3}(x)-T_{2}(x)\right) d x=M^{\prime \prime} c_{p}^{\prime \prime} d T_{3}(x)
$$

where:

$$
\begin{aligned}
& K_{1}-\text { the coefficient of the heat exchange from the actuating me- } \\
& \text { dium to the air, } \\
& D-\text { the diameter of the flue tube (given), } \\
& M^{\prime \prime}=M_{g}\left(L_{0}+1\right) \alpha-\text { the mass consumption of the actuating medium, } \\
& C^{\prime \prime}-\text { heat capacity of the actuating medium under the tempera- } \\
& \text { ture } T_{3} .
\end{aligned}
$$


The permanent heat exchange of the reiterative air with the actuating medium and environment can be presented with the following equation:

$$
K_{1} \pi D\left(T_{3}(x)-T_{2}(x)\right) d x-K_{2} \pi D_{0} T_{2}(x)-T_{0}(x) d x=M^{\prime} C_{p}^{\prime} d T_{2}
$$

where:

$K_{2}$ - the coefficient of heat transmission from the reiterative air into environment through the casing with the given diameter $D_{0}$ under the temperature of the environment $T_{0^{\prime}}$

$C_{p}$ - the air heat capacity under the temperature $T_{2}$.

The equation for the heat balance of the combustion area is the following:

$$
T_{30} C_{p}^{\prime \prime}\left(\alpha L_{0}+1\right)=\alpha L_{0} C_{p}^{\prime} T_{2 L}+\left(\alpha_{1} L_{0}+1\right) C_{p} T_{03}
$$

where:

$T_{30}$ - the intake temperature of the actuating medium into the mixing zone,

$T_{03}$ - the torch temperature in the combustion area,

$T_{2 L}$ - the intake temperature of the primary air into the combustion area that comes with the surplus coefficient,

$C_{p}$ - the heat capacity of the combustion products under the temperature $T_{03}$.

The joint answer of the equations (23)-(25) under the specified intake temperature in the combustion chamber $T_{2}$ and the temperature of the actuating medium in the blade of the directing set of the high pressure turbine $T_{3}$ can be given as the following:

$$
\begin{aligned}
& \left(\left(\left(T_{2 i}-T_{0 i}\right) /\left(1-W_{T}\left(K_{T} / W_{m}+K_{0} / W_{g}-\sqrt{\left(K_{T} / W_{m}+K_{0} / W_{m}\right)-4 K_{0} K_{T} / W_{T} W_{g}} /\right.\right.\right.\right. \\
& \left./ 2 K_{T}+T_{0 i}\right) C_{p}^{\prime \prime}\left(\alpha L_{0}+1\right)-\left(\alpha L_{0}+1\right) C_{p} T_{03} / \alpha L_{0}-T_{0 i}=1-W_{T}\left(K_{T} / W_{m}+K_{0} / W_{g}\right)- \\
& \left.-\sqrt{\left(K_{T} / W_{m}+K_{0} / W_{m}\right)-4 K_{0} K_{T} / W W_{g}} / 2 K_{T}\right)\left(T_{3 i}-T_{0 i}-\left(\alpha_{1} L_{0}+1\right) C_{P} T_{03} / \alpha L_{0}-\right. \\
& -T_{0 i}\left(\operatorname { e x p } \left(-\left(\left(K_{T} / W_{m}+K_{0} / W_{g}\right)+\sqrt{\left.\left(K_{T} / W_{m}+K_{0} / W_{m}\right)-4 K_{0} K_{T} / W_{T} W_{g}\right)}\right) \frac{L}{2}-\right.\right. \\
& -\left(\exp \left(-\left(\left(K_{T} / W_{m}+K_{0} / W_{g}\right)-\sqrt{\left.\left(K_{T} / W_{m}+K_{0} / W_{m}\right)-4 K_{0} K_{T} / W_{T} W_{g}\right)}\right) \frac{L}{2}\right)\right),
\end{aligned}
$$

where:

$W_{g^{\prime}} W_{T}$ - the water equivalents of the air and actuating medium correspondingly:

$$
W_{g}=C_{p}^{\prime} M^{\prime} W_{T}=C_{p}^{\prime \prime} M^{\prime \prime}
$$


$W_{m}$ - the mixed water equivalent:

$$
W_{m}=W_{g}^{\prime \prime} W_{T} /\left(W_{g}+W_{T}\right)
$$

$K, K_{0}$ - the given coefficients of heat transmission from the actuating medium to the reiterative air and from the reiterative air into the environment.

\section{Conclusions}

The present mathematical model allow us for the determination of the given heat transmission coefficients $K_{n}$ and $K_{0}$ as well as the intake reiterative air in the mixing zone of the combustion chamber temperature $T_{2 L}$, if the operation parameters of GTU in three modes are known. Whereupon the technological modes due to which the combustion chamber is diagnosed differ by the intake air temperature of the axial-flow compressor, the output actuating medium temperature into the directing set of the high pressure turbine as well as the temperature of the environment. Besides, the steady-state conditions of GTU operation are adhered to on every mode.

Thus, the given mathematical model of the burning processes in the combustion chamber will enable not only the determination of the key features of the combustion chamber but also to study the basic technological modes to decrease the emission of the polluted substances of the adjacent territories of compressor stations.

Such an approach will enable the carrying out various computations and studies as well as determine the indicated indices of exhaust combustion products and develop the ecological characteristics under the different operative modes of the GTU.

\section{References}

[1] Paton B.Ye., Khalatov A., Kostenko D., Bileka B., Pys'mennyy O., Botsula A., Parafiynyk V., Konyakhin V.: Kontseptsiya (proekt) Derzhavnoyi naukovo-tekhnichnoyi prohramy «Stvorennya promyslovykh hazoturbinnykh doyhuniv novoho pokolinnya dlya hazovoyi promyslovosti ta enerhetyky» [Патон Б.Є., Халатов А., Костенко Д., Білека Б., Письменний О., Боцула А., Парафійник В., Коняхін В.: Концеепиія (проект), Державної науково-технічної програми «Створення промислових газотурбінних двигунів нового покоління для газової промисловості та енергетики»]. Visnyk NAN Ukrayiny, no. 4, 2008, pp. 3-9.

[2] Romanovs'kyy H.F., Serbin S.I.: Kamery zhoryannya sudnovykh hazoturbinnykh dvyhuniv. Navchal'nyy posibnyk [Романовський Г.Ф., Сербін C.I.: Камери згоряння суднових газотурбінних двигунів. Навчальний посібник]. UDMTU, Mykolayiv 2000. 
[3] Postnikov A.M.: Snizheniye oksidov azota v vykhlopnykh gazakh GTU [Постников А.М.: Снижение оксидов азота в выхлопных газах ГТУ]. Yzdatel'stvo Samarskoho Nauchnoho Tsentra RAN, Samara 2002.

[4] Lefevr A.: Protsessy v kamerakh sgoraniya GTD [Лефевр А.: Процессь в камерах сгорания ГТ,Д]. Mir, Moskva 1986 [translation from English].

[5] Khristich V.A., Tumanovskiy A.G.: Gazoturbinnyye dvigateli $i$ zashchita okruzhayushchey sredy [Христич В.А., Тумановский А.Г.: Газотурбинные двигатели и защита окружающей средь]. Tekhnika, Kiyev 1983.

[6] Willis J.D., Moran A.J.: Industrial RB211 DLE Gas Turbine Combustion Update. ASME Turbo Expo 2000: Power for Land, Sea, and Air, GT2000-109, ASME, 2000.

[7] Andreini A., Facchini B., Mangani L., Asti A., Ceccherini G., Modi R.: NOx Emissions Reduction in an Innovative Industrial Gas Turbine Combustor (GE10 Machine): A Numerical Study of the Benefits of a New Pilot System of Flame Structure and Emissions. Proceedings of the ASME Turbo Expo, Volume 2, GT200568364, ASME, 2005.

[8] Wilkes C., Mongia H.C., Santanam C.B.: An ultra-low NOX combustion system for a 3.5 MW industrial gas turbine. 90-GT-83, ASME, 1990.

[9] Serbyn S.Y., Mostypanenko A.B.: Udoskonalennya kharakterystyk kamery zhoryannya hazoturbinnoho doyhuna $z$ vykorystannyam metodiv tryoymirnoho modelyuvannya [Сербин С.И., Мостипаненко А.Б Удосконалення характеристик камери згоряння газотурбінного двигуна з використанням методів тривимірного моделювання]. Visnyk NUK, no. 1, NUS, Mykolayiv 2010, [on-line:] http://evn.nuos.edu.ua/article/view/24629/22106.

[10] Shnee Ya.I.: Teоriya gazovykh turbin [Шнеэ Я.И.: Теория газовых турбин]. Mashinostroyeniye, Moskva 1979. 